\title{
Penggunaan Bokashi Kulit Buah Rambutan Untuk Meningkatkan Pertumbuhan Dan Hasil Tanaman Kangkung Darat (Ipomoea resptans Poir)
}

\author{
Herlina Kurniawati dan Susilo Arifin \\ Fakultas Pertanian Universitas Kapuas Sintang \\ Email: herlina_kurniawati@yahoo.com
}

\begin{abstract}
Abstrak: Kangkung darat merupakan sayuran yang bernilai ekonomi dan sebaranya cukup luas. Upaya yang dapat dilakukan agar produksi kangkung darat dapat ditingkatkan adalah dengan mengunakan pupuk organik dalam bentuk bokashi kulit buah rambutan. Penelitian ini bertujuan untuk mengetahui pengaruh bokashi kulit buah rambutan terhadap pertumbuhan dan hasil tanaman kangkung darat dan dosis bokashi yang memberikan pengaruh terbaik terhadap pertumbuhan dan hasil tanaman kangkung darat. Lingkup penelitian ini meliputi beberapa variabel yaitu: variabel bebas adalah pelakuan bokashi kulit buah rambutan; variabel terikat yaitu terdiri dari tinggi tanaman dan berat segar tanaman. Rancangan yang digunakan pada penelitian adalah Rancangan Acak Kelompok (RAK) satu faktor dengan perlakuan bokashi kulit buah rambutan terdiri dari 6 level, masing-masing level diulang sebanyak 5 kali. Untuk mengetahui pengaruh perlakuan terhadap yang diamati dilakukan analisis ragam (Uji F) pada taraf nyata $5 \%$ dan $1 \%$. Jika pada uji F perlakuan menunjukkan pengaruh yang nyata maka akan dilanjutkan dengan uji Beda Nyata Jujur (BNJ). Hasil penelitian menunjukkan bahwa bokashi kulit buah rambutan berpengaruh terhadap pertumbuhan dan hasil tanaman kangkung darat. Pemberian $2,5 \mathrm{~kg}$ dapat meningkatkan pertumbuhan dan hasil tanaman kangkung darat, rata-rata tinggi tanaman yang dihasilkan 23,9 cm dan rata-rata berat segar per tanaman $39,65 \mathrm{~g}$.
\end{abstract}

Kata Kunci : Bokashi, Produksi, Kangkung Darat, Pertumbuhan, Hasil

\section{PENDAHULUAN}

Kangkung darat (Ipomoea reptans Poir) merupakan salah satu anggota famili Convolvulaceae. Tanaman kangkung digolongkan sebagai tanaman sayur. Kangkung darat merupakan sayuran yang bernilai ekonomi dan sebaranya cukup luas di daerah Asia Tenggara. Beberapa negara yang merintis pembudidayaan tanaman kangkung secara intensif dan komersial adalah Taiwan, Thailand, Filipina, dan Indonesia. Kangkung darat umumnya dikonsumsi oleh masyarakat Indonesia dan dapat menjadi salah satu menu di rumah-rumah makan (Rukmana, 1994:20). Kangkung memiliki kandungan gizi yang lengkap, di antaranya protein, lemak, karbohidrat, serat, kalsium, fosfor, zat besi, natrium, kalium, vitamin A, B, C, dan karoten (Polii, 2009:14).

Umumnya tanaman kangkung darat hanya ditanam di lahan pekarangan dan sebagian kecil yang ditanam secara intensif dilahan kering, sehingga optimalisasi produksi kangkung masih kurang. Secara umum produksi kangkung darat di Kabupaten Sintang masih rendah rata-rata 1,56 ton/ ha (BPS Kalbar, 2015:203), sedangkan potensi produksi kangkung darat mencapai 25-30 ton/ha (PT.East West Seed Indonesia, 2015:1).
Kurangnya produktifitas kangkung darat di Kabupaten Sintang dikarenakan terdapat banyaknya tanah podsolik merah kuning (PMK). Menurut Badan Statistik Sintang (2015:60) tanah podsolik merah kuning di Kabupaten Sintang adalah 42,89\% dari luas keseluruhan wilayah Kabupaten Sintang.

Upaya yang dapat dilakukan agar produksi kangkung darat dapat ditingkatkan adalah dengan mengunakan pupuk organik dalam bentuk bokashi kulit buah rambutan. Kulit buah rambutan adalah bahan organik sisa dari produksi tanaman buah rambutan yang belum dimanfaatkan dengan baik dan berpotensi untuk digunakan sebagai bahan bokashi. Berdasarkan hal tersebut maka perlu dilakukan penelitian mengunakan perlakuan bokashi kulit buah rambutan untuk mengetahui pengaruhnya terhadap pertumbuhan dan hasil tanaman kangkung darat (Ipomoea reptans Poir). Penelitian ini bertujuan untuk mengetahui 1) pengaruh bokashi kulit buah rambutan terhadap pertumbuhan dan hasil tanaman kangkung darat; 2) dosis bokashi kulit buah rambutan yang memberikan pertumbuhan dan hasil tanaman kangkung darat. 


\section{METODOLOGI PENELITIAN}

\section{Metode Penelitian}

Percobaan ini menggunakan metode eksperimen lapangan dan menggunakan rancangan lingkungan dengan pola Rancangan Acak Kelompok (RAK), Faktor perlakuan dalam percobaan ini adalah bokashi kulit buah rambutan yang terdiri dari 6 taraf diulang 5 kali, seperti berikut ini: $\mathrm{P}_{0}=$ tidak diberi bokashi kulit buah rambutan; $\mathrm{P}_{1}=0,5 \mathrm{~kg}$ bokashi kulit buah rambutan $/ \mathrm{m}^{2} ; \mathrm{P}_{2}=1$ $\mathrm{kg}$ bokashi kulit buah rambutan $/ \mathrm{m}^{2} ; \mathrm{P}_{3}=1,5 \mathrm{~kg}$ bokashi kulit buah rambutan $/ \mathrm{m}^{2} ; \mathrm{P}_{4}=2 \mathrm{~kg}$ bokashi kulit buah rambutan $/ \mathrm{m}^{2} ; \mathrm{P}_{5}=2,5 \mathrm{~kg}$ bokashi kulit buah rambutan $/ \mathrm{m}^{2}$.

Percobaan ini terdiri dari 6 taraf bokashi kulit buah rambutan $\times 5$ ulangan $\times 16$ tanaman $=$ 480 tanaman satuan percobaan. Satuan pengamatan dalam penelitian adalah 4 tanaman $x$ 6 taraf perlakuan x 5 ulangan $=120$ tanaman pengamatan.

\section{Waktu dan tempat penelitian}

Penelitian dilaksanakan di Dusun Sumber Harapan Desa Sei Risap Kecamatan Binjai Hulu

\section{Bahan dan Alat Penelitian}

Bahan-bahan percobaan terdiri dari benih kangkung darat, digunakan untuk bahan percobaan; kulit buah rambutan, digunakan untuk perlakuan percobaan; pupuk kandang, digunakan untuk mencampur bokashi kulit buah rambutan; larutan EM4 sebagai bahan pengurai kulit buah rambutan; air gula untuk campuran bokashi kulit buah rambutan.

Alat percobaan terdiri dari parang dan cangkul digunakan untuk pembersihan dan pengolahan lahan; gergaji dan palu digunakan untuk membuat papan perlakuan; gembor digunakan untuk menyiram tanaman; alat tulis digunakan untuk menulis data; timbangan sawit digunakan untuk menimbang bokashi kulit buah rambutan; kamera digunakan untuk dokumentasi; timbangan digital untuk menimbang berat segar tanaman; meteran digunakan untuk mengukur tinggi tanaman; terpal digunakan untuk alas pembuatan bokashi kulit buah rambutan; gunting di gunakan untuk menggunting tanaman saat seleksi; termometer sebagai pengukur suhu bokashi

Kabupaten Sintang. Waktu penelitian dimulai bulan Februari sampai April 2018.

\section{HASIL DAN PEMBAHASAN}

\section{Hasil Penelitian}

Hasil pengamatan dalam penelitian ini untuk peubah tinggi tanaman dan berat segar tanaman disajikan pada Tabel 1 berikut.

Tabel 1. Rerata tiap peubah

\begin{tabular}{ccc}
\hline \multirow{2}{*}{ Perlakuan } & \multicolumn{2}{c}{ Rerata } \\
\cline { 2 - 3 } & Tinggi tanaman $(\mathbf{c m})$ & Berat segar tanaman $($ gram) \\
\hline $\mathbf{P}_{\mathbf{0}}$ & 13,65 & 24,60 \\
$\mathbf{P}_{1}$ & 16,70 & 27,45 \\
$\mathbf{P}_{\mathbf{2}}$ & 17,05 & 27,75 \\
$\mathbf{P}_{\mathbf{3}}$ & 17,75 & 28,95 \\
$\mathbf{P}_{\mathbf{4}}$ & 18,25 & 31,20 \\
$\mathbf{P}_{5}$ & 23,90 & 39,65 \\
\hline Jumlah & $\mathbf{1 7 , 8 8}$ & $\mathbf{2 9 , 9 3}$ \\
\hline
\end{tabular}

Sumber: Data hasil pengamatan, 2018.

Keterangan: $\mathrm{P}_{0}=$ tidak diberi bokashi kulit buah rambutan $\mathrm{P}_{1}=0,5 \mathrm{~kg}$ bokashi kulit buah rambutan $/ \mathrm{m}^{2} \mathrm{P}_{2}=1 \mathrm{~kg}$ bokashi kulit buah rambutan $/ \mathrm{m}^{2} \mathrm{P}_{3}=1,5 \mathrm{~kg}$ bokashi kulit buah rambutan $/ \mathrm{m}^{2} \mathrm{P}_{4}=2 \mathrm{~kg}$ bokashi kulit buah rambutan $/ \mathrm{m}^{2} \mathrm{P}_{5}=2,5 \mathrm{~kg}$ bokashi kulit buah rambutan $/ \mathrm{m}^{2}$ 
Hasil dari Tabel 1 yang ditampilkan menunjukkan rerata tinggi tanaman tertinggi terlihat pada pemberian 2,5 $\mathrm{kg}$ bokashi kulit buah rambutan $\left(\mathrm{P}_{5}\right)$ dengan tinggi rata-rata $23,9 \mathrm{~cm}$, dan rerata tinggi tanaman terendah dihasilkan pada tanaman yang tidak diberi bokashi kulit buah rambutan $\left(\mathrm{P}_{0}\right)$ dengan tinggi tanaman rata-rata $13,65 \mathrm{~cm}$. Ratarata berat segar tanaman kangkung darat mengikuti taraf pemberian bokashi kulit buah rambutan, semakin banyak diberikan pada tanaman maka tanaman semakin berat. Pemberian 2,5 kg bokashi kulit buah rambutan $\left(\mathrm{P}_{5}\right)$ menghasilkan berat segar rata-rata per tanaman tertinggi dengan tinggi 39,65 $\mathrm{g}$, dan tanaman kangkung darat yang tidak diberikan bokashi kulit buah rambutan $\left(\mathrm{P}_{0}\right)$ menghasilkan rata-rata tinggi tanaman terendah yaitu $24,6 \mathrm{~g}$.

Nilai rerata dari pengamatan tinggi tanaman dan berat segar tanaman kemudian dilanjutkan dengan analisis sidik ragam seperti yang ditampilkan dalam Tabel 2.

Tabel 2. Analisis ragam perlakuan terhadap tiap peubah

\begin{tabular}{clccc}
\hline \multirow{2}{*}{ SK } & \multicolumn{1}{c}{ F hitung } & \multicolumn{2}{c}{ F tabel } \\
\cline { 2 - 5 } & $\begin{array}{c}\text { Tinggi } \\
\text { tanaman }\end{array}$ & $\begin{array}{c}\text { Berat segar } \\
\text { tanaman }\end{array}$ & $\mathbf{0 , 0 5}$ & $\mathbf{0 , 0 1}$ \\
\hline Kelompok & $4,59^{\text {ns }}$ & $15,89 * *$ & 4,24 & 5,29 \\
Perlakuan & $82,41^{* *}$ & $49,93 * *$ & 4,24 & 5,29 \\
\hline
\end{tabular}

Sumber : Hasil analisis data

Keterangan: $\quad$ tn $=$ tidak berpengaruh nyata,

$*$ = berpengaruh nyata pada selang kepercayaan $95 \%$,

$* *$ = berpengaruh sangat nyata pada selangkepercayaan $99 \%$

Hasil analisis sidik ragam pada Tabel 2 diketahui bahwa pemberian Bokashi Kulit Buah Rambutan untuk peubah tinggi tanaman kangkung darat menunjukan bahwa $\mathrm{F}$ hitung kelompok $<\mathrm{F}$ tabel 0,05 sehingga tidak berpengaruh nyata, sedangkan $\mathrm{F}$ hitung perlakuan $>\mathrm{F}$ tabel 0,01 sehingga berpengaruh sangat nyata.

Untuk mengetahui perbedaan pengaruh bokashi kulit buah rambutan terhadap tinggi tanaman dan berat segar tanaman, maka Tabel 3. Uji beda nyata jujur (BNJ) terhadap tiap peubah

\begin{tabular}{|c|c|c|}
\hline \multirow{2}{*}{ Perlakuan } & Tinggi tanaman & Berat segar tanaman \\
\hline & \multicolumn{2}{|c|}{ Rerata } \\
\hline $\mathbf{P}_{0}$ & $13,65 \mathrm{a}$ & $24,60 \mathrm{a}$ \\
\hline $\mathbf{P}_{1}^{0}$ & $16,70 \mathrm{~b}$ & $27,45 \mathrm{~b}$ \\
\hline $\mathbf{P}_{2}^{1}$ & $17,05 \mathrm{~b}$ & $27,75 \mathrm{~b}$ \\
\hline $\mathbf{P}_{3}^{2}$ & $17,75 \mathrm{~b}$ & $28,95 \mathrm{bc}$ \\
\hline $\mathbf{P}^{3}$ & $18,25 \mathrm{~b}$ & $31,20 \mathrm{c}$ \\
\hline $\mathbf{P}_{5}^{4}$ & $23,90 \mathrm{c}$ & $39,65 \mathrm{~d}$ \\
\hline Bर́NJ 0.05 & 1.56 & 3.15 \\
\hline BNJ 0,01 & 1,95 & 3,93 \\
\hline
\end{tabular}

Sumber : Hasil analisis data

Keterangan: Angka yang diikuti huruf yang sama pada kolom yang sama menunjukkan berbeda tidak nyata.
Pengaruh bokashi kulit buah rambutan terhadap berat segar tanaman kangkung darat menunjukan bahwa $\mathrm{F}$ hitung kelompok $>\mathrm{F}$ tabel 0,0 maka hasilnya berpengaruh sangat nyata, dan F hitung perlakuan bokashi kulit buah rambutan > $F$ tabel 0,01 sehingga juga berpengaruh sangat nyata.

dilanjutkan dengan uji BNJ yang dapat dilihat pada Tabel 3. 


\section{Penggunaan Bokashi Kulit Buah Rambutan Untuk Meningkatkan Pertumbuhan Dan Hasil Tanaman Kangkung Darat (Ipomoea resptans Poir)}

Hasil uji BNJ (Tabel 3) menunjukan bahwa pemberian bokashi kulit buah rambutan $2,5 \mathrm{~kg}$ menghasilkan tinggi tanaman lebih tinggi dari perlakuan yang lainnya $(23,9 \mathrm{~cm})$ dan berbeda dengan perlakuan lainnya. Perlakuan tanpa pemberian bokashi kulit buah rambutan menunjukkan rerata tinggi terendah dan berbeda dengan perlakuan lainnya. Pemberian $0,5 \mathrm{~kg}, 1 \mathrm{~kg}$, $1,5 \mathrm{~kg}$ dan $2 \mathrm{~kg}$ bokashi kulit buah rambutan tidak berbeda satu sama lain, tetapi berdeda dengan pemberian 2,5 $\mathrm{kg}$ dan tanpa pemberian bokashi kulit buah rambutan.

Hasil uji BNJ pengaruh bokashi kulit buah rambutan pada berat segar tanaman kangkung darat menunjukkan perlakuan $2,5 \mathrm{~kg}$ berdeda dengan semua perlakuan lainnya, demikian juga dengan perlakuan tanpa bokashi kulit buah rambutan. Pemberian $0,5 \mathrm{~kg}$ dan $1 \mathrm{~kg}$ tidak berbeda nyata dengan pemberian $1,5 \mathrm{~kg}$, sementara pemberian $1,5 \mathrm{~kg}$ tidak berbeda nyata dengan pemberian $2 \mathrm{~kg}$ bokashi kulit buah rambutan.

\section{Pembahasan}

Hasil penelitian menunjukan pemberian bokashi kulit buah rambutan berpengaruh terhadap pertumbuhan dan hasil tanaman kangkung darat, ditunjukan oleh tinggi tanaman dan berat segar tanaman. Hal ini menunjukkan bahwa bokashi kulit buah rambutan dapat meningkatkan pertumbuhan dan hasil tanaman kangkung darat. Pemberian bokashi kulit buah rambutan diduga menyebabkan hara $\mathrm{N}, \mathrm{P}$, dan $\mathrm{K}$ menjadi lebih tersedia bagi tanaman, karena bokashi kulit buah rambutan mempunyai kandungan $\mathrm{N}$, $\mathrm{P}$, dan $\mathrm{K}$ yang merupakan salah satu unsur hara esensial bagi tanaman (Lingga dan Marsono, 2012:36-37). Peningkatan pertumbuhan dan hasil tanaman kangkung darat pada tanah PMK akibat pemberian bokashi kulit buah rambutan tidak terlepas dari peran fisiologis $\mathrm{N}, \mathrm{P}$, dan $\mathrm{K}$ karena merupakan unsur hara yang diperlukan dalam metabolisme tanaman.

Hasil penelitian menunjukkan bahwa semakin tinggi dosis bokashi kulit buah rambutan yang diberikan maka pertumbuhan tanaman semakin meningkat. Sebelumnya hasil penelitian Kurniawati dan Very (2019:9) juga menunjukkan bahwa pemberian bokashi eceng gondok dengan dosis tertinggi sebanyak $5 \mathrm{~kg}$ memberikan pengaruh terbaik terhadap pertumbuhan dan hasil tanaman sawi hijau, yang ditunjukkan oleh jumlah daun dan berat segar tertinggi tanaman. Hal ini diduga karena pemberian bokashi kulit buah rambutan selain sebagai bahan organik yang berperan dalam memperbaiki sifat fisik tanah PMK, namun juga sebagai suplai hara karena mengandung unsur $\mathrm{N}$, $\mathrm{P}$, dan $\mathrm{K}$ yang mampu meningkatkan pertumbuhan tinggi dan berat segar tanaman kangkung darat.

Pemberian bokashi kulit buah rambutan pada tanah PMK di penelitian ini menyebabkan meningkatkan drainase dan aerasi tanah serta mengaktifkan kerja mikroorganisme tanah melalui peranannya sebagai bahan organik. Peranan ini mengakibatkan tanah menjadi lebih remah dan mengaktifkan akar tanaman dalam menyerap garam-garam mineral dari unsur hara dalam tanah. Tinggi tanaman dan berat segar tanaman tertinggi yang diperoleh dengan pemberian 2,5 $\mathrm{kg}$ bokashi kulit buah rambutan yang berbeda nyata dengan perlakuan lainnya, menunjukkan bahwa peranan bokashi sebagai bahan organik dalam memperbaiki sifat tanah telah mendukung pertumbuhan dan hasil tanaman kangkung darat. Hal ini didukung oleh penelitian Kurniawati (2018:362) yang menunjukkan bahwa pemberian sebanyak $2 \mathrm{~kg}$ bokashi kulit rambutan menghasilkan tinggi tanaman dan berat segar tanaman rata-rata tertinggi pada tanaman bayam cabut.

\section{KESIMPULAN}

Berdasarkan hasil penelitian maka dapat disimpulkan:

Bokashi kulit buah rambutan berpengaruh terhadap pertumbuhan dan hasil tanaman kangkung darat.

Pemberian 2,5 kg bokashi kulit buah rambutan dapat meningkatkan pertumbuhan dan hasil tanaman kangkung darat, rata-rata tinggi tanaman yang dihasilkan $23,9 \mathrm{~cm}$ dan rata-rata berat segar per tanaman 39,65 gram. 


\section{SARAN}

Saran dari penelitian ini adalah:

Bokashi kulit buah rambutan dapat digunakan untuk meningkatkan pertumbuhan dan hasil tanaman kangkung darat.

Dosis $2,5 \mathrm{~kg}$ bokashi kulit buah rambutan dapat diberikan pada tanaman kangkung darat agar pertumbuhan dan hasilnya baik.

\section{DAFTAR PUSTAKA}

Badan Pusat Statistik Kalimantan Barat. 2015. Kalimantan Barat Dalam Angka. BPS Propinsi Kalimantan Barat. Pontianak.

Badan Pusat Statistik Kabupaten Sintang. 2015. Kabupaten Sintang Dalam Angka. BPS Kabupaten Sintang. Sintang.

Cahayani, S. 2003. Pengaruh pemberian Bokashi terhadap sifat fisik dan mekanik tanah serta pertumbuhan Tanaman pak choy (Brasisca chinensis L). Skripsi. IPB Repository. Diakses tanggal 12 Juni 2016.

Dwidjoseputro, 1992. Fisiologi Tumbuhan. Rhineka Cipta. Jakarta.

Gaspersz, 1999. Metode Perencanaan Percobaan. Amico. Bandung

Hardjadi, M.S. 1991. Pengantar Agronomi. Cetakan ke-16. Gramedia Pustaka Utama. Jakarta.

Kurniawati, H. 2018. Pemanfaatan Kulit Rambutan Sebagai Bokashi Untuk Meningkatkan Pertumbuhan dan Hasil Bayam Cabut (Amaranthus tricolor, L). Jurnal PIPER Fakultas Pertanian Universitas Kapuas Sintang. Nomor 27. Volume 14. Hal. 357-364.
Kurniawati, H dan Very, K. 2019. Peningkatan pertumbuhan dan hasil sawi hijau )Brassica juncea L) dengan pemberian bokashi eceng gondok (Eichornoa crassipes). Jurnal PIPER Fakultas Pertanian Universitas Kapuas Sintang. Nomor 28. Volume 15. Hal. 1-11.

Lingga, P dan Marsono. 2012. Petunjuk Penggunaan Pupuk. Penebar Swadaya. Jakarta.

Maria, G.M. 2009. Respon Produksi Tanaman Kangkung Darat (Ipomoea resptans Poir) Terhadap Variasi Waktu Pemberian Pupuk Kotoran Ayam. Jurnal Ilmu Tanah. Edisi 7. Hal.18-22.

Polii, MG.M. 2009. Respon Produksi Tanaman kangkung Darat (Ipomoea resptans Poir). Buletin Hortikultura. Edisi 25. Hal.23-25

Prasetyo, D.H dan Suriadikarta, D.A. 2010. Karakteristik Potensi Dan Teknologi Pengolahan Tanah Ultisol Untuk Pengembangan Pertanian Lahan kering di Indonesia. Jurnal Litbang Pertanian. Edisi 25. Hal.1-12

Rukmana, R. 1994. Bertanam Kangkung. Kanisius. Yogyakarta

Salisbury, F.A. dan Ross, C.W. 1992. Fisiologi Tumbuhan I. Diterjemahkan oleh D.R Lukman dan Sumaryono. ITB Press. Bandung. 